\title{
APLIKASI PENDEKATAN PEMBELAJARAN SAINTIFIK METODE INQUIRY BASED LEARNING PADA KOMPETENSI DASAR MENERAPKAN HUKUM-HUKUM YANG BERHUBUNGAN DENGAN FLUIDA STATIS DAN DINAMIS UNTUK MENINGKATKAN HASIL BELAJAR SISWA KELAS X SMK
}

\author{
Mahzum
}

\section{Abstrak}

Tahun pelajaran 2013/2014 seluruh SMA dan SMK Negeri di Indonesia mulai mengimplementasi kurikulum 2013. Proses pembelajaran kurikulum 2013 pada jenjang tersebut dilaksanakan dengan menerapkan pendekatan saintifik. Cakupan pendekatan saintifik ini meliputi tiga ranah yaitu pengembangan sikap, keterampilan, dan pengetahuan. Penerapan pendekaan saintifik dirangkai dengan salah satu metode pembelajaran yaitu metode inquiry based learning atau problem based learning atau project based learning. Penilaian hasil belajar dengan pendekatan saintifik telah dipatok KKMnya sebesar 75 yang setara dengan 2,66 atau B-.

Dari uraian tersebut penulis mencoba melakukan peneletian tindakan kelas untuk mengetahui kegiatan aplikasi pendekatan pembelajaran saintifik metode inquiry based learning pada kompetensi dasar menerapkan hukum-hukum yang berhubungan dengan fluida statis dan dinamis, dan untuk mengetahui peningkatan hasil belajar kompetensi dasar tersebut pada siswa kelas X TKBT2 SMK Negeri 3 Semarang tahun pelajaran 2013/2014.

Penelitian tindakan kelas ini menggunakan 2 siklus pada pokok bahasan tekanan hidrostatik,gaya Archimedes,hukum Pascal,tegangan permukaan,viskositas dan hukum Stokes. Siklus pertama diberlakukan pada pokok bahasan tekanan hidrostatik,gaya Archimedes,hukum Pascal. Siklus kedua diberlakukan pada pokok bahasan tegangan permukaan,viskositas dan hukum Stokes.

Data hasil belajar diambil melalui observasi dan tes. Data observasi untuk memperoleh nilai sikap dan nilai keterampilan, data tes untuk mem- 
peroleh nilai pemahaman. Data dianalisis dengan menggunakan analisis kuantitaif dibantu program SPSS versi 17.0 dan dibantu dengan grafi. Pada siklus pertama rata-rata nilai ranah sikap 76,57 rata-rata nilai ranah ketarmpilan 76,67 dan rata-rata nilai ranah pemahman 75,60. Sedangkan pada siklus kedua rata-rata nilai ranah sikap 80,56, rata-rata nilai ranah keterampilan 81,86, dan rata-rata ranah pemahaman 80,54.

Kesimpulan bahwa kegiatan yang dirancang dalam aplikasi pembelajaran dengan pendekatan saintifik metode inquiry based learning pada kompetensi dasar menerapkan hukum-hukum yang berhubungan dengan fluida statis dan dinamis sesuai dengan landasan teori, dan dapat meningkatkan hasil belajar siswa kelas X SMK.

Kata Kunci: Pendekatan Pembelajaran saintifik metode inquiry based learning, kompetensi dasar menerapkan hukum-hukum yang berhubungan dengan fluida statis dan dinamis, hasil belajar siswa.

\section{PENDAHULUAN}

Menurut Daryanto (2013:45) pelajaran fisika tidak mungkin berkembang bila tidak disertai dengan peningkatan pembelajaran yang bermutu. Pembelajaran yang bermutu sangat dibutuhkan setiap orang. Dengan demikian diharapkan terwujudnya transformasi pengetahuan yang cepat dan mudah diakses oleh setiap guru.

Kompetensi dasar menerapkan hukum-hukum yang berhubungan dengan fluida statis dan dinamis merupakan kompetensi dasar lanjutan yang harus ditopang oleh kompetensi dasar sebelumnya. Untuk menguasai kompetensi dasar ini terlebih dahulu harus menguasai kompetensi dasar sebelumnya terutama kompetensi dasar menerapkan hukum Newton dan konsep gaya. Dengan demikian di SMK pembelajaran kompetensi dasar ini harus benar-benar memberi kesan yang mendalam bagi siswa, sehingga kedepan mampu menyelesaikan masalah dalam kehidupan sehari-hari yang berkaitan dengan kompetensi dasar tersebut.

Pemerintah mengamanatkan bahwa seluruh sekolah negeri setingkat SMA/SMK di Indonesia mulai tahun pelajaran 2013/2014 harus mengimplementasi kurikulum 2013. Proses pembelajaran kurikulum 2013 pada jenjang tersebut dilaksanakan dengan menerapkan 
pendekatan saintifik. Cakupan pendekatan saintifik meliputi tiga ranah yaitu pengembangan sikap, keterampilan, dan pengetahuan. Penerapan pendekaan saintifik dirangkai dengan salah satu metode pembelajaran yaitu metode inquiry based learning atau problem based learning atau project based. Disamping itu dalam penilaian hasil belajar telah dipatok Kriteria Ketuntasan Minimum (KKM) sebesar 75 yang setara dengan 2,66 atau B-.

Dari uraian tersebut di atas penulis mencoba meneliti peningkatan hasil belajar siswa kelas X TKBT2 SMK Negeri 3 Semarang melalui aplikasi pendekatan pembelajaran saintifik metode inquiry based learningpada kompetensi dasar menerapkan hukum-hukum yang berhubungan dengan fluida statis dan dinamis.

\section{TUJUAN PENELITIAN}

Penelitian ini memiliki 2 tujuan yaitu, untuk mengetahui kegiatan aplikasi pendekatan pembelajaran saintifik metode inquiry based learning pada kompetensi dasar menerapkan hukum-hukum yang berhubungan dengan fluida statis dan dinamis, dan untuk mengetahui peningkatan hasil belajar kompetensi dasar tersebut pada siswa kelas X TKBT2 SMK Negeri 3 Semarang Tahun Pelajaran 2013/2014 setelah menerapkan pendekatan pembelajaran saintifik metode inquiry based.

\section{KAJIAN PUSTAKA}

\section{Hasil Belajar}

Menurut Agus Suprijono (2011:5) hasil belajar adalah pola-pola perbuatan, nilai-nilai, pengertian-pengertian, sikap-sikap, apresiasi dan keterampilan. Menurut Daryanto (2013:66) belajar sebagai hasil, dimana guru melihat bentuk terakhir dari berbagai pengalaman interaksi edukatif. Perhatian pada penampakan sifat dan tanda-tanda perilaku yang dipelajari. Dari situ terdapat klasifikasi hasil yang perlu dimiliki seorang murid yaitu hasil dalam bentuk keterampilan, bentuk konsep, dan bentuk sikap.

Menurut Soetomo (2011:100) dalam “Taxonomi of Educational Objectives" hasil belajar dibedakan menjadi tiga ranah atau sasaran 
pendidikan yaitu ranah kognitif, afektif dan psikomotorik. Ranah kognitif meliputi 6 kategori tipe hasil belajar yaitu, 1) Tipe hasil belajar pengetahuan hafalan (knowledge).Pengetahuan ini diurutkan dari yang paling sederhana sampai yang agak abstrak. 2) tipe hasil belajar pemahaman yang meliputi kemampuan menerjemahkan, menafsirkan, dan ekstrapolasi (ramalan kemungkinan). 3) tipe aplikasi yaitu kemampuan menerapkan suatu abstraksi pada situasi konkrit atau situasi khusus.4) tipe hasil belajar analisis yaitu pemahanan memisahkan menjadi bagian-bagian yang terpadu. Tipe belajar ini dibagi menjadi yaitu analisis unsur, analisis hubungan, dan analisis prinsip. 5) tipe belajar sintesis yang merupakan landasan berfikir kreatif, antara lain menghasilkan komunikasi, menghasilkan rencana, dan kecakapan mengabstraksi. 6) tipe hasil belajar evaluasi adalah kemampuan memberikan keputusan tentang nilai sesuatu dengan menggunakan sudut pandang tertentu.

Ranah afektif meliputi kategori menyimak, menanggapi, memberi nilai (menghargai), mengorganisasi nilai, karakterisasi nilai. Sedangkan ranah psikomotorik meliputi kategori mengindera, kesiagaan diri, bertindak secara terpimpin, bertindak secara mekanik, bertindak secara kompleks.

\section{Pendekatan Pembelajaran Saintifik}

Di dalam makalah materi implementasi kurikulum 2013 definisi pendekatan saintifik adalah proses pembelajaran yang dirancang sedemikian rupa agar peserta didik secara aktif mengonstruk konsep, hukum atau prinsip melalui tahapan-tahapan mengamati (untuk mengidentifikasi atau menemukan masalah), merumuskan masalah, mengajukan atau merumuskan hipotesis, mengumpulkan data dengan berbagai teknik, menganalisis data, menarik kesimpulan dan mengkomunikasikan konsep, hukum atau prinsip yang "ditemukan". Pendekatan saintifik dimaksudkan untuk memberikan pemahaman kepada peserta didik dalam mengenal, memahami berbagai materi menggunakan pendekatan ilmiah, bahwa informasi bisa berasal dari mana saja, kapan saja, tidak bergantung pada informasi searah dari guru. Oleh karena itu kondisi pembelajaran yang 
diharapkan tercipta diarahkan untuk mendorong peserta didik dalam mencari tahu dari berbagai sumber melalui observasi, dan bukan hanya diberi tahu.

Penerapan pendekatan saintifik dalam pembelajaran melibatkan keterampilan proses seperti mengamati, mengklasifikasi, mengukur, meramalkan, menjelaskan, dan menyimpulkan. Dalam melaksanakan proses-proses tersebut, bantuan guru diperlukan. Akan tetapi bantuan guru tersebut harus semakin berkurang dengan semakin bertambah dewasanya siswa atau semakin tingginya kelas siswa.

Beberapa tujuan pembelajaran dengan pendekatan saintifik adalah: 1) untuk meningkatkan kemampuan intelektual, khususnya kemampuan berpikir tingkat tinggi siswa.2) untuk membentuk kemampuan siswa dalam menyelesaikan suatu masalah secara sistematik.3) terciptanya kondisi pembelajaran dimana siswa merasa bahwa belajar itu merupakan suatu kebutuhan.4) diperolehnya hasil belajar yang tinggi. 5) untuk melatih siswa dalam mengkomunikasikan ide-ide, khususnya dalam menulis artikel ilmiah. 6) untuk mengembangkan karakter siswa.

Beberapa prinsip pendekatan saintifik dalam kegiatan pembelajaran diantaranya, 1) pembelajaran berpusat pada siswa. 2) pembelajaran membentuk students' self concept. 3) pembelajaran terhindar dari verbalisme. 4) pembelajaran memberikan kesempatan pada siswa untuk mengasimilasi dan mengakomodasi konsep, hukum, dan prinsip. 5) pembelajaran mendorong terjadinya peningkatan kemampuan berpikir siswa. 6) pembelajaran meningkatkan motivasi belajar siswa dan motivasi mengajar guru. 7) memberikan kesempatan kepada siswa untuk melatih kemampuan dalam komunikasi. 8) adanya proses validasi terhadap konsep, hukum, dan prinsip yang dikonstruksi siswa dalam struktur kognitifnya.

Proses pembelajaran pada Kurikulum 2013 untuk semua jenjang dilaksanakan dengan menggunakan pendekatan ilmiah (saintifik). Langkah-langkah pendekatan ilmiah (scientific approach) dalam proses pembelajaran meliputi menggali informasi melalui pengamatan, bertanya, percobaan, kemudian mengolah data atau 
informasi, menyajikan data atau informasi, dilanjutkan dengan menganalisis, menalar, kemudian menyimpulkan, dan mencipta.

Penilaian pada pembelajaran dengan pendekatan saintifik meliputi penilaian proses, penilaian produk, dan penilaian sikap. Penilaian pada 3 ranah tersebut dapat dijelaskan sebagai berikut: 1) Penilaian proses atau keterampilan, dilakukan melalui observasi saat siswa bekerja kelompok, bekerja individu, berdiskusi, maupun saat presentasi dengan menggunakan lembar observasi kinerja.2) penilaian produk berupa pemahaman konsep, prinsip, dan hukum dilakukan dengan tes tertulis. 3) penilaian sikap melalui observasi saat siswa bekerja kelompok, bekerja individu, berdiskusi, maupun saat presentasi dengan menggunakan lembar observasi sikap.

\section{Metode Belajar Inquiry based Learning}

Menurut Sigit Mangun Wardoyo (2013:32) inquiry based learning adalah proses berfikir kritis dan analitis untuk mencari dan menemukan sendiri jawaban dari suatu masalah yang dihadapi dengan berbagai sunber informasi sebagai pendukungnya. Menurut Abdul Majid (2013:221-222) inquiry based learning merupakan metode pembelajaran yang menekankan kepada proses menemukan. Peran siswa dalam metode pembelajaran ini adalah mencari dan menemukan sendiri materi pelajaran, sedangkan guru berperan sebagai fasilitator dan pembimbing siswa dalam belajar.

Jadi metode inquiry based learning menekankan ada proses berfikir kritis dan analitis untuk mencari dan menemukan sendiri jawaban dari suatu masalah yang dipertanyakan. Proses berfikir itu sendiri biasanya dilakukan melalui tanya jawab antara guru dan siswa.

Ciri-ciri metode Inquiry based Learning meliputi: pertama, metode Inquiry based learning menekankan kepada aktivitas siwa secara maksimal untuk mencari dan menemukan. Artinya metode Inquiry based learningmenempatkan siswa sebagai subjek belajar. Dalam proses pembelajaran, siswa tidak hanya berperan sebagai penerima pelajaran melalui penjelasan guru secara verbal, tetapi juga 
mereka berperan untuk menemukan sendiri inti dari materi pelajaran itu sendiri.

Kedua, seluruh aktivitas yang dilakukan siswa diarahkan untuk mencari dan menemukan jawaban sendiri dari suatu yang dipertanyakan sehingga diharapkan dapat menumbuhkan sikap percaya diri (self-belief). Dengan demikian, metode Inquiry based learningmenempatkan guru bukan sebagai sumber belajar, tetapi sebagai fsilitator dan motivator belajar siswa. Aktivitas pembelajaran biasanya dilakukan melalui proses tanya jawab antara guru dan siswa. Oleh karena itu, kemampuan guru dalam menggunakan teknik bertanya merupakan syarat utama dalam melakukan inkuiri. Dan ketiga, tujuan dari penggunaan metode Inquiry based learningadalah mengembangkan kemampuan berfikir secara sistematis, logis, dan kritis, atau mengembangkan kemampuan intelektual sebagai bagian dari proses mental.

Dengan demikian, dalam metode Inquiry based learning siswa tak hanya dituntut untuk menguasai materi pelajaran, tetapi juga bagaimana mereka dapat menggunakan potensi yang dimilikinya. Siswa yang hanya menguasai pelajaran belum tentu dapat mengambangkan kemampuan berfikir secara optimal. Sebaliknya, siswa akan dapat mengembangkan kemampuan berfikirnya manakala ia bisa menguasai materi pelajaran.

Prinsip Penggunaan metode Inquiry based terdiri dari a) berorientasi pada pengembangan intelektual.Tujuan utama dari metode ini adalah pengembangan kemampuan berfikir. Dengan demikian, metode ini selain berorientasi kepada hasil belajar juga berorientasi pada proses belajar. b) prinsip interaksi, proses pembelajaran pada dasarnya adalah proses interaksi, baik interaksi antara siswa maupun interaksi siswa dengan guru, bahkan interaksi interaksi siswa dengan lingkungan. Pembelajaran sebagai proses interaksi berarti menempatkan guru bukan sebagai sumber belajar, melainkan sebagai pengatur interaksi itu sendiri.c) prinsip bertanya, peran guru yang harus dilakukan dalam menggunakan metode Inquiry based learning ini adalah guru sebagai penanya karena kemampuan siswa untuk menjawab setiap pertanyaan pada dasarnya sudah merupak- 
an sebagian dari proses berfikir. Oleh karena itu, kemampuan guru untuk bertanya dalam setiap langkah inkuiri sangat diperlukan. d) prinsip belajar untuk berfikir, belajar bukan hanya mengingat sebuah fakta, tetapi juga merupakan proses berfikir (learning how to think), yakni proses mengembangkan potensi seluruh otak secara maksimal. e) prinsip keterbukaan pembelajaran yang bermakna adalah pembelajaran yang menyediakan berbagai kemungkinan sebagai hipotesis yang harus dibuktikan kebenaranya. Tugas guru adalah menyediakan ruang untuk memberikan kesempatan kepada siswa berkembang hipotesis dan secara terbuka membuktikan kebenaran hipotesis yang diajukan.

Sintaks pelaksanaan metode Inquiry based learning sesuai menurut Sanjaya dalam Wardoyo (2010:210) meliputi orientasi, merumuskan masalah, mengajukan hipotesis, mengumpulkan data, menguji hipotesis, dan merumuskan. Orientasi merupakan awal untuk mencari informasi mengenai masalah yang ditemui. Selanjutnya diiedentifikasi dan dirumuskan masalahnya. Dengan perumusan masalah tersebut diajukan hipotesis sementara. Dari sini dicarikan data penunjang untuk diuji untuk menemukan jawaban oermasalahan tersebut dan akhirnya dapat disimpulkan.

\section{Kompetensi Dasar (KD) Menerapkan Hukum-Hukum Yang Ber- hubungan Dengan Fluida Statis Dan Dinamis}

Pada penelitian ini KD menerapkan hukum-hukum yang berhubungan dengan fluida statis dan dinamis dibatasi pada pokok bahasan tekanan hidrostatik, gaya archimedes, hukum pascal, tegangan permukaan,viskositas dan hukum stokes. Pembatasan ini diasumsikan pada silabus yang memiliki alokasi waktu 4 jam pelajaran untuk pokok bahasan tersebut dan 2 jam untuk pokok bahasan hukum Bernoulli.

\section{METODE PENELITIAN}

Subjek penelitian adalah siswa kelas X TKBT2 SMK Negeri 3 Semarang tahun pelajaran 2013/2014. Penelitian ini merupakan penelitian tindakan kelas dengan menggunakan 2 siklus. Masing-ma- 
sing siklus diperlakukan 4 tahap penelitian sebagaimana dijelaskan oleh Maman Rahman (2008:75) dalam bukunya Penelitian Tindakan Kelas. Prosedur dan langkah-langkah penelitian ini mengikuti prinsip yang berlaku dalam PTK dengan skema Kurt Lewin yang disajikan sebagai berikut:

Gambar 1: Skema Alur PTK Menurut Kurt Lewis

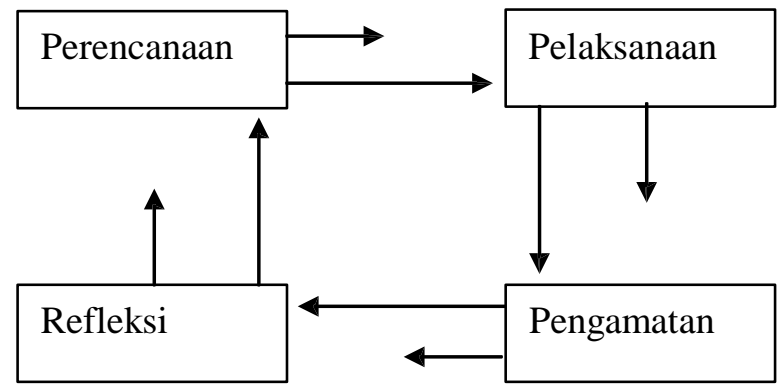

Keterangan:

Siklus 1

Siklus 2

Secara rinci tahapan-tahapan dalam setiap siklus adalah, a) tahap perencanaan yang meliputi pertama, Peneliti merumuskan masalah yang diambil dari pokoksuhu dan kalor. Kedua, Peneliti membuat 2 Rencana Pelaksanaan Pembelajaran dengan pendekatan saintifik metode inquiry based learningpada pokok bahasan yang akan diajarkan. Ketiga, membuat lembar observasi untuk menilai pola interaksi dalam pembelajaran yang meliputi nilai keterampilan dan nilai sikap. Keempat, meyusun kisi-kisi tes dan menyusun soal tes pemahaman. b) tahap tindakan yang meliputi pertama, Peneliti melaksanakan rencana yang telah disusun. Kedua, Peneliti merekam kejadian-kejadian pada saat penelitian berlangsung dengan checklist. c) tahap pengamatan terdiri dari 2 perlakuan pengamatan pertama, Peneliti melakukan pengamatan di dalam proses pembelajaran dengan melakukan penskoran di dalam lembar observasi yang telah disiapkan. Kedua, Peneliti mengamati hasil tes kemampuan siswa. c) tahap refleksi, dari data pengamatan dapat digu- 
nakan untuk melakukan refleksi terhadap perencanaan dan tindakan yang telah dilakukan. Adanya kelemahan yang terjadi pada siklus pertama segera dicarikan solusi alternatif untuk mendukung temuan kelebihan-kelebihannya. Selanjutnya hasil refleksi tersebut dijadikan acuan untuk melakukan penelitian pada siklus kedua.

\section{HASIL PENELITIAN DAN PEMBAHASAN Analisis Kegiatan Pada Siklus Pertama}

Pada siklus pertama pendekatan pembelajaran saintifik metode inquiry based learning diaplikasikan pada pokok bahasan tekanan hidrostatik, gaya archimedes, dan hukum pascal. Tindakan diawali dengan memperlihatkan video seorang yang sedang menyelam di pantai, kapal yang sedang berlabuh, dan dongkrak hidrolik. Siswa mengamati tayangan video dan digiring untuk menanyakan sesuatu yang berkaitan dengan tekanan hidrostatis, mengapung, dan prinsip pascal berdasarkan fenomena tersebut. Siswa dibagi menjadi 7 kelompok dan setiap kelompok diberi bahan ajar dan LKS sebagai pendukung. LKS berisi pertanyaan-pertanyaan yang menggiring siswa untuk merumuskan masalah, membuat hipotesis, mencari data, dan menyimpulkan. Pada akhir diskusi setiap kelompok memperesentasikan hasil diskusi dihadapan kelompok lain.

Pada saat diskusi dan presentasi dilaksanakan pula observasi untuk mendapatkan data nilai sikap dan data nilai keterampilan. Selesai tindakan dilakukan tes untuk mendapatkan data nilai pemahaman.

Analisis penelitian meliputi analisis data observasi dan data tes. Data observasi terdiri dari data nilai sikap dan data nilai keterampilan, sedangkan data tes merupakan nilai pemahaman.Kriteria Ketuntasan Minimum (KKM) nilai sikap, nilai ketermpilan, dan nilai pemahaman masing-masing sama sebesar 75. Kategori sikap terdiri dari cukup baik(CB), baik(B), sangat baik(SB). Katergori keterampilan mencakup cukup terampil(CTr), terampil(Tr), sangat terampil(STr). Kategori pemahaman hanya mencakup tidak tuntas(TT) dan rtuntas(T). Statistik hasil analisis disajikan pada tabel 1. 
Hasil analisis nilai sikap menunjukkan bahwa mean 76,57, artinya rata-rata sikap pembelajaran siswa mengarah pada kategori baik (B). Nilai (tengah) median nilai sikap yang diperoleh siswa 76,00 menunjukkan kategori sikap siswa dalam pembelajaran berada pada posisi baik (B). Sedangkan sering muncul (mode) yang diperoleh siswa 76 berarti mayoritas siswa bersikap baik dalam proses pembelajaran.

Tabel 1: Statistik Siklus Pertama Hasil Analisis Nilai Sikap,

Keterampilan, Pemahaman

\begin{tabular}{|l|c|c|c|c|c|c|}
\hline Statistik & Sikap 1 & $\begin{array}{c}\text { Kat- } \\
\text { egori }\end{array}$ & Keterampilan1 & Kategori & $\begin{array}{c}\text { Pemaha- } \\
\text { man1 }\end{array}$ & $\begin{array}{c}\text { Kat- } \\
\text { egori }\end{array}$ \\
\hline $\begin{array}{l}\text { Jumlah } \\
\text { Siswa }\end{array}$ & 35 & & 35 & & 35 & \\
\hline Mean & 76.57 & $\mathrm{~B}$ & 76.67 & $\mathrm{Tr}$ & 75.60 & $\mathrm{~T}$ \\
\hline Median & 76.00 & $\mathrm{~B}$ & 76.50 & $\mathrm{Tr}$ & 75.00 & $\mathrm{~T}$ \\
\hline Mode & $76(60 \%)$ & $\mathrm{B}$ & $76.67(14,3 \%)$ & $\mathrm{Tr}$ & $75(57.1 \%)$ & $\mathrm{T}$ \\
\hline Minimum & $74(2,9 \%)$ & $\mathrm{CB}$ & $70.00(2.9 \%)$ & $\mathrm{CTr}$ & $70(2.9 \%)$ & $\mathrm{TT}$ \\
\hline Maximum & $84(2,9 \%)$ & $\mathrm{B}$ & $83.00(2.9 \%)$ & $\mathrm{Tr}$ & $84(2.9 \%)$ & $\mathrm{T}$ \\
\hline Sum & 2680 & & 2683.33 & & 2646 & \\
\hline
\end{tabular}

Mean dari nilai keterampilan 76,57 artinya rata-rata siswa pada saat pembelajaran berlangsung mengarah pada kategori terampil (Tr). Nilai (tengah) median nilai sikap yang diperoleh siswa 76,00 menunjukkan bahwa kategori siswa dalam pembelajaran berada pada posisi terampil (Tr). Sedangkan sering muncul (mode) yang diperoleh siswa 76,00 berarti mayoritas siswa terampil dalam proses pembelajaran.

Mean dari nilai pemahaman 75,00 artinya rata-rata siswa pada saat pembelajaran berlangsung mengarah pada kategori tuntas (T). Nilai (tengah) median nilai pemahaman yang diperoleh siswa 75,00 menunjukkan bahwa kategori siswa dalam pembelajaran berada pada posisi tuntas (T). Sedangkan sering muncul (mode) yang diperoleh siswa 75 berarti mayoritas siswa tuntas dalam pembelajaran. 
Berdasarkan analisis data nilai sikap, nilai keterampilan, dan nilai pemahaman di atas dapat dilakukan refleksi sebagai berikut: Pertama, dari analisis data nilai sikap, nilai keterampilan, dan nilai pemahaman masih terdapat nilai minimum masing-masing 2,5\% dengan kategori cukup baik, cukup terampil, dan tidak tuntas. Kedua, harga mean, median, dan mode yang nyaris sama dengan KKM menunjukkan bahwa sikap belajar siswa masih pas-pasan. Ketiga, nilai maksimum sikap, keterampilan, dan pemahaman masing-masing 2,5\% berada pada kategori yang sama dengan mean yaitu baik, terampil, dan tuntas. Akibatnya tidak tampak penyebaran data hasil belajar sampai pada kategori sangat baik, sangat terampil, dan tuntas. Memperhatikan refleksi di atas, maka diperlukan tindakan lebih lanjut agar pembelajaran dengan penerapan pendekatan saintifik metode inquiry based learning menghasilkan prestasi belajar yang lebih bagus. Untuk itu diperlukan tindakan selanjutnya pada siklus kedua.

\section{Analisis Kegiatan Pada Siklus Kedua}

Pada siklus kedua pendekatan pembelajaran saintifik metode inquiry based learning diaplikasikan pada pokok bahasan tegangan permukaan,viskositas dan hukum stokes. Tindakan diawali dengan siswa mengamati fenomena jarum yang terapung di atas permukaan air, bola bergerak dengan kecepatan berbeda di dalam fluida yang beda kekentalanya pada tayangan vidio.

Selesai dari pengamatan siswa didorong untuk bertanya sesuatu yang berkaitan dengan fenomena tersebut. Selanjutnya siswa berdiskusi sesuai dengan kelompoknya berdasarkan panduan beru- pa bahan ajar dan LKS. Hasil diskusi disimpulkan dan dipresen- tasikan. Pada saat diskusi dan presentasi guru mengamati dengan bantuan lembar pengamatan dan selesai tindakan siswa diberi tes.

Data hasil observasi dan tes dianalisis untuk memperoleh statistik pada tabel 2. Hasil analisis nilai sikap menunjukkan bahwa mean 80,24, artinya rata-rata sikap pembelajaran siswa mengarah pada kategori baik (B). Nilai (tengah) median nilai sikap 
yang di- peroleh siswa 80,00 menunjukkan kategori sikap siswa dalam pem- belajaran berada pada posisi baik (B). Sedangkan sering muncul (mode) yang diperoleh siswa 79,75 berarti mayoritas siswa bersikap baik dalam proses pembelajaran.

Mean dari nilai keterampilan 81,86 artinya rata-rata siswa pada saat pembelajaran berlangsung mengarah pada kategori terampil (Tr). Nilai (tengah) median nilai sikap yang diperoleh siswa 81,83 menunjukkan bahwa kategori siswa dalam pembelajaran berada pada posisi terampil (Tr). Sedangkan sering muncul (mode) yang diperoleh siswa 81,83 berarti mayoritas siswa terampil dalam proses pembelajaran.

Tabel 2: Statistik Siklus Kedua Hasil Analisis Data Nilai Sikap, Keterampilan, Pemahaman

\begin{tabular}{|l|c|c|c|c|c|c|}
\hline \multicolumn{1}{|c|}{ Statistik } & Sikap 2 & $\begin{array}{c}\text { Kat- } \\
\text { egori }\end{array}$ & Keterampilan2 & $\begin{array}{c}\text { Kat- } \\
\text { egori }\end{array}$ & Pemahaman2 & $\begin{array}{c}\text { Kat- } \\
\text { egori }\end{array}$ \\
\hline Jumlah Siswa & 35 & & 35 & & 35 & \\
\hline Mean & 80.24 & $\mathrm{~B}$ & 81.86 & $\mathrm{Tr}$ & 80.54 & $\mathrm{~T}$ \\
\hline Median & 80.00 & $\mathrm{~B}$ & 81.83 & $\mathrm{Tr}$ & 80.00 & $\mathrm{~T}$ \\
\hline Mode & $79.75(20 \%)$ & $\mathrm{B}$ & $81.83(22.9 \%)$ & $\mathrm{Tr}$ & $80(22.9 \%)$ & $\mathrm{T}$ \\
\hline Minimum & $75.25(2.9 \%)$ & $\mathrm{B}$ & $76.00(2.9 \%)$ & $\mathrm{Tr}$ & $76(8.6 \%)$ & $\mathrm{T}$ \\
\hline Maximum & $85.75(2.9 \%)$ & $\mathrm{SB}$ & $90.66(2.9 \%)$ & $\mathrm{STr}$ & $88(2.9 \%)$ & $\mathrm{T}$ \\
\hline \multicolumn{1}{|c|}{ Sum } & 2808.50 & & 2865.1667 & & 2819 & \\
\hline
\end{tabular}

Mean dari nilai pemahaman 80,54 artinya rata-rata siswa pada saat pembelajaran berlangsung mengarah pada kategori tuntas (T). Nilai (tengah) median nilai pemahaman yang diperoleh siswa 80,00 menunjukkan bahwa kategori siswa dalam pembelajaran berada pada posisi tuntas (T). Sedangkan sering muncul (mode) yang diperoleh siswa 80 berarti mayoritas siswa tuntas dalam pembelajaran.

Berdasarkan analisis data nilai sikap, nilai keterampilan, dan nilai pemahaman di atas dapat dilakukan refleksi sebagai berikut: Pertama, dari analisis data tidak terdapat nilai di bawah KKM. Ni- 
lai minimum dari semua ranah melampaui KKM. Ini artinya seluruh siswa minimal bersikap baik, terampil, dan tuntas. Kedua, harga mean, median, dan mode fantastis karena jauh melampaui KKM. Ini mengindikasikan siswa memiliki semangat belajar untuk meraih hasil belajar yang gemilang. Ketiga, nilai maksimum sikap, keterampilan, dan pemahaman berada pada kategori sangat baik, sangat terampil, dan tuntas, walaupun jumlah siswa pada kategori ini hanya $2,5 \%$.

Memperhatikan refleksi di atas, maka penelitian ini cukup diperlukan tindakan sampai pada siklus kedua dalam mengaplikasikan pendekatan saintifik metode inquiry based learning pada pokok bahasan tekanan hidrostatik, gaya archimedes, hukum pascal, tegangan permukaan, viskositas dan hukum stokes.

\section{Pembahasan Hasil Penelitian}

Berdasarkan analisis data pada siklus pertama dan siklus kedua siswa mengalami peningkatan hasil belajar kompetensi dasar menerapkan hukum-hukum yang berhubungan dengan fluida statis dan dinamis. Rekapitulasi data dengan jelas dan nyata menunjukkan peningkatan hasil belajar. Grafik peningkatan hasil belajar ranah sikap, ranah keterampilan, dan ranah pemahaman disajikan sebagai berikut:

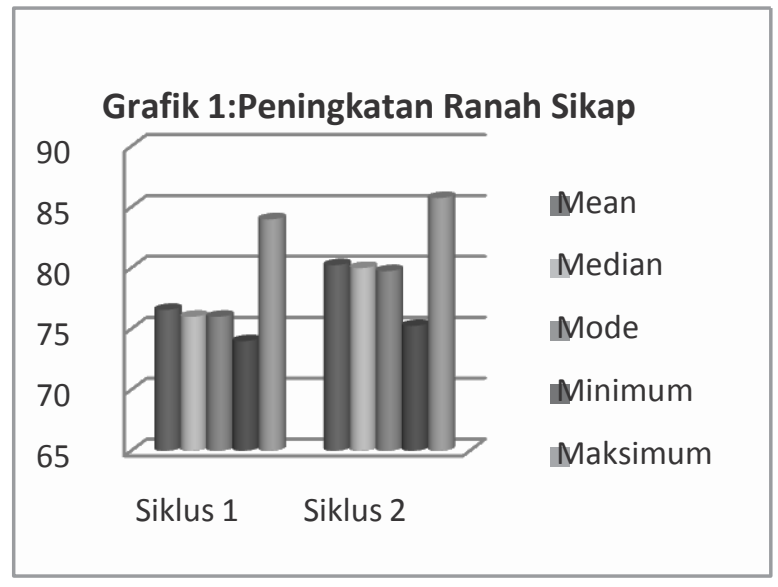


Peningkatan nilai sikap dikarenakan siswa telah terbiasa dalam pembelejaran dengan pendekatan saintifik inquiry based learning. Siswa dalam diskusi kelompok sangat antusias terbukti masingmasing siswa aktif, mau bekerja sama dengan rekan-rekannya, dan selalu berusaha mencari tahu tentang topik yang dihadapinya.

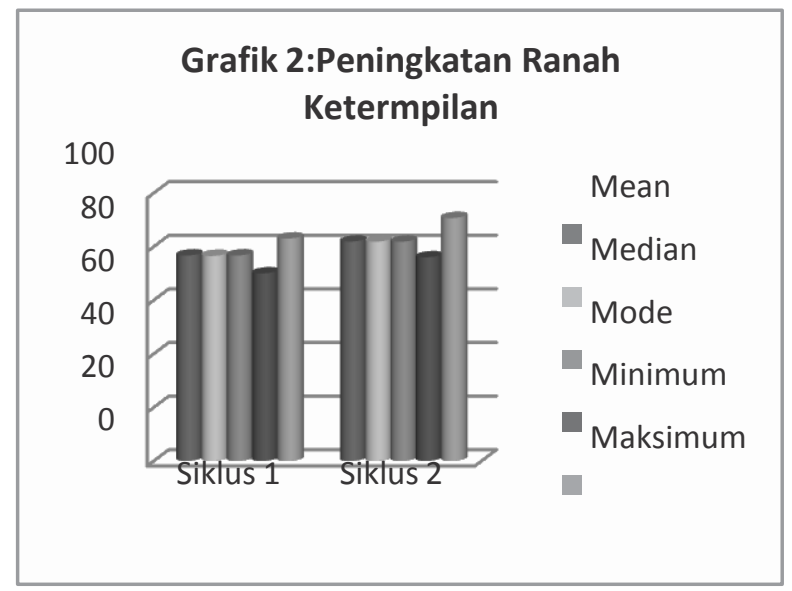

Peningkatan hasil belajar keterampilan dari siklus pertama ke siklus kedua mengindikasikan adnya kesibukan siswa dalam praktikum. Masing-masing siswa bekerjasama untuk mencermati langkah-langkah kerja pada LKS. Gairah kerja untuk segera selesai melaksanakan praktikum dan telaah bahan ajar dengan benar seolah-olah masing-masing kelompok berpacu dalam belajar.

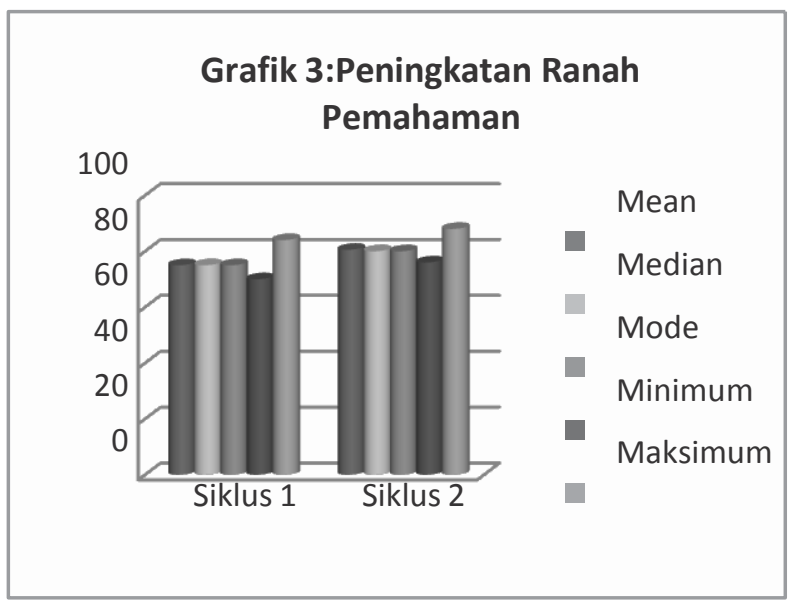


Peningkatan hasil belajar pemahaman dari siklus pertama ke siklus kedua. Peningkatan ini menggambarkan siswa memahami pokok bahasan tekanan hidrostatik, gaya archimedes, hukum pascal, tegangan permukaan, viskositas dan hukum stokes yang telah dipelajarinya.

\section{PENUTUP}

Berdasarkan hasil penelitian tindakan kelas pada siswa SMK Negeri 3 Semarang dapatdisimpulkan bahwa kegiatan aplikasi pendekatan pembelajaran saintifik metode inquiry based learning pada kompetensi dasar menerapkan hukum-hukum yang berhubungan dengan fluida statis dan dinamis sesuai dengan landasan teori pendekatan saintifik metode inquiry based kearning. Kesimpulan lain aplikasi pendekatan pembelajaran saintifik inquiry based learning dapat meningkatkan hasil belajar kompetensi dasar menerapkan hukum-hukum yang berhubungan dengan fluida statis dan dinamis.

Adapun saran yang diajukan perlu indicator lebih banyak dalam penilaian sikap ketika observasi. Siswa dipacu lebih optimal agar menghasilkan prestasi yang lebih baik. juga pada saat pengambilan nilai keterampilan guru lebih cermat dan teliti. Pengambilan nilai pemahaman harus benar-benar obyektif, Bila perlu dilengkapi dengan penilaian teman sejaeat, penilaian diri, forto foilio, dan prnilaian

proyek. 


\section{DAFTAR PUSTAKA}

Abdul Majid, Strategi Pembelajaran, Bandung: PT. Remaja Rosdakarya, 2013

Agus Sulisto, dan Adi Mulyono, Kamus Lengkap Bahasa Indonesia, Surakarta: ITA.

Agus Suprijono, kooperatif learning, Yogyakarta: Pustaka Pelajar, 2011.

Daryanto, Inovasi Pembelajaran Efektif, Bandung: Yrama Widya 2013.

Maman Rachman, Penelitian Tindakan Kelas, Semarang: Unnes, 2008.

Modul Pelatihan dan pendampingan implementasi kurikulum 20013, SMK N 3 Semarang.

Rudi Hartono, Ragam Metode yang Mudah Diterima Murid, Yogyakarta: Diva Press, 2013.

Sigit Mangun Wardoyo, Pembelajaran Berbasis Riset, Purbalingga: Akademia, 2013.

Soetomo, WE, Perancangan dan Pengembangan Sistem Pembelajaran, Semarang: YSBI Kanthil, 2011

Sugiyono, Metode Penelitian Pendidikan, Bandung: Alfabeta, 2010. 